Marais, E. A journey through digital storytelling during COVID-19: Students' preparedness to use technology for learning in the language classroom

\title{
A journey through digital storytelling during COVID-19: Students' preparedness to use technology for learning in the language classroom
}

\author{
Elma Marais \\ North-West University, Potchefstroom, South Africa \\ Email: elma.marais@nwu.ac.za \\ Received : 2021-06-11 \\ Revised : 2021-07-21 \\ Accepted : 2021-08-30 \\ $10.46303 /$ ressat.2021.17
}

\begin{abstract}
How to cite this paper: Marais, E. (2021) A journey through digital storytelling during COVID-19: Students' preparedness to use technology for learning in the language classroom. Research in Social Sciences and Technology, 6(2), 169-182. https://doi.org/10.46303/ressat.2021.17

This is an Open Access article distributed under the terms of the Creative Commons Attribution 4.0 International license (https://creativecommons.org/licenses/by/4.0/).
\end{abstract}

\begin{abstract}
The COVID-19 pandemic has forced lecturers at South African universities to reconceptualise their teaching and learning activities. Universities had to embark on remote teaching to salvage the 2020 academic year. This created the opportunity to draw on students' creative and digital skills to promote digital storytelling as a way of enhancing their learning experience. This article describes the journey of a teacher educator and a group of students registered for a language didactics module in an initial teacher education programme. Film study was traditionally presented through lively conversations in a contact session where students could exchange their perceptions and opinions regarding various aspects of film. Because of the COVID-19 lockdown this approach had to be reviewed. The lecturer in question employed digital learning competencies to transform learning through the innovative use of digital tools and resources to rethink student engagement with film. Students were invited to create digital stories. The outcome of the process not only improved their understanding of teaching film but also promoted their digital competencies and empowered them to create resources they could use in their careers.
\end{abstract}

Keywords: Digital storytelling; film study; digital competencies; COVID-19

\section{Introduction}

Sam Walton, the founder of Walmart, (Walton, 1992) once said: "Many of our best opportunities were created out of necessity", a notion entirely consonant with the possibilities inherent in the educational situation that COVID-19 has forced upon our children and university students. Educators and students alike are finding themselves in unfamiliar territory. Although distance learning has been a part of our institutions for some time, we are all scrambling to find 
Marais, E. A journey through digital storytelling during COVID-19: Students' preparedness to use technology for learning in the language classroom

the best way to facilitate online teaching for students who previously attended face-to-face contact sessions on campus. The question of teaching is one side of the coin, the other being the development of students' digital competencies, especially those of future teachers and in the context of COVID-19 (Jackman et al., 2021; König et al., 2020; Intrenational Labour Organization \& Bank, 2021; Perifanou, 2021).

Within teacher training language courses, literary study has always been a cornerstone, with film study becoming more and more important in recent years. Literature and film studies are traditionally associated with lively discussion within a classroom, where students could give their opinions on what the literary or filmic work aims to say and how such a text could be used in teaching at school (Ahn, 2020; Stephens et al., 2012). This is not possible within the context of COVID-19, especially in an unequal society like South Africa's where not all students have access to devices and stable internet all the time. In a classroom setting a lecturer could show students a full-length film and the camera angles, lighting and much more could be discussed. As students had no access to campus, not only could the film not be shown or given to students because of copyright laws, most students were unable to hire Afrikaans films or download them on streaming services. This led to a rethinking of the module, and of how students might differently engage with the content knowledge of drama and film while imagining how filmic concepts and conventions might be introduced in the intermediate phase language classroom.

The aim of the article is to report on the changes implemented and on students' perceptions of these changes. The focus is on a task where students had to create their own animated voiceover films, written drama, and report on how they would use these in the classroom. The students also comment on how they engaged with the technology used to create the film and why they chose the film that they did (see research question under the methodology).

\section{Review of Literature}

\section{Film as part of teacher training courses}

At the university in question, there is a module that focusses on the integration of drama and film in the intermediate phase (Marais, 2020). This module combines content knowledge of drama and film with pedagogical knowledge to prepare intermediate phase students to use drama and film to facilitate language learning. The aim is to equip future teachers not only with the capacity to use drama and film texts to facilitate language learning, but also with the ability to engage with a new generation of children who are more familiar with visual technology in a variety of forms. Within the South African curriculum, film study is not an outcome in the intermediate phase (SA, 2011), and therefore can be used with much more freedom within the language classroom in that phase. According to Robin (2016), digital storytelling can be a powerful educational tool for students of all ages. Moreover, if students are given the opportunity to share their work with their peers, they gain valuable experience in critiquing not only their own work but those of other students.

Film making encourages students' creativity and gives them control over what they deem appropriate and what they want to use it for (Robin, 2016). 
Marais, E. A journey through digital storytelling during COVID-19: Students' preparedness to use technology for learning in the language classroom

\section{Digital competencies of pre-service teachers}

It is becoming increasingly important that in their pre-service years, student teachers start to explore the use of new technology in their teaching, especially in the context of COVID-19. Within the current curriculum, they might encounter technology as part of assignments, microlessons, or compulsory teaching practice at schools. The integration of technology into teacher training has become essential, especially in the light of the Digital Framework presented by the South African Government in 2019 (SA, 2019). Pre-service teachers must be prepared for presenting content knowledge through the use of technology and made to understand that the use of technology is strictly functional, a way of facilitating learning.

It is widely acknowledged that future teachers and in-service teachers should have adequate if not comprehensive knowledge regarding the integration of technology in the classroom (Martines et al., 2019; Robinson \& Aronica, 2015; Tamika et al., 2021; Tondeur, 2018; Tondeur et al., 2019). This is also a growing field within the South African context. In his State of the Nation address on 7 February 2019, the President of South Africa stated that the government would like a tablet in every child's hand to aid their learning by 2025 (De Villiers, 2019). This is not a new notion in South Africa, since a White paper on e-Education in 2004 asserted that South Africa needed to transform learning and teaching through the development and integration of Information and Communication Technologies (ICT)(SA, 2004). The Department of Basic Education has set out the digital learning competencies and digital literacy skills that teachers need for teaching in the digital age (SA, 2019). South Africa has struggled in this regard because of budget constraints, gaps in teachers' technical knowledge, and even crime in instances when schools have been broken into and equipment stolen.

Aside from these problems, there is still a drive to develop our teachers' and pre-service teachers' digital competencies. The Digital Framework identifies thirteen competencies that are required of teachers, ranging from the competencies of beginner teachers to highly developed literacy, numeracy and information technology (IT) skills (SA, 2019). In this project, the focus was on the transformation of learning through the innovative use of digital tools and resources (SA, 2019).

The Digital Learning Competency 8 - transforming learning through the innovative use of digital tools and resources - is achieved if teachers (or, in the case of this project, students) are able to do the following:

- Explore new uses for established digital tools and resources;

- Explore opportunities offered by new digital tools and resources;

- Facilitate learning that was not possible before the introduction of digital tools and resources;

- Understand the impact of digital tools and resources on the nature of learning.

The Department of Basic Education (SA, 2019) goes on to say that the knowledge, skills and attitudes that a teacher or student could acquire could include a spirit of being innovative, exploring the potential value of new digital tools for learning, and implementing new approaches to learning. 
Marais, E. A journey through digital storytelling during COVID-19: Students' preparedness to use technology for learning in the language classroom

Tondeur et al. (2019) claim that it is becoming more and more important for teacher educators to prepare prospective teachers for the presentation of material through the use of various technologies. Teacher educators need to bridge the gaps that prospective teachers might have with regard to their technology, pedagogy and content knowledge (TPACK) (Koehler et al., 2013). Tondeur et al. (2016) and Tondeur (2018) concede that trying to prepare pre-service teachers for the effective integration of technology, so that technology adds to the learning experience and is not used simply for its own sake, is a complex process (Aslan \& Chang, 2016).

According to Tondeur et al. (2016), pre-service teachers do not use technology during their preservice work-integrated learning as they do not have the skills nor the knowledge (besides the use of PowerPoint) about how effectively to integrate technology. Aslan and Chang (2016) claim that new teachers should have the knowledge and skills to plan and prepare content using aspects of technology that facilitate learning. They also need the motivation to do so (Tondeur et al., 2016). Hammond et al. (2009) cite several reasons why students might not embrace the use of technology. These include teachers' pedagogical beliefs, innovativeness, workload, the school's access to ICT infrastructure and the school's culture. He asserts that there is a need for in-service teachers to be assisted with access to and the use of technology (Hammond et al., 2009; Ohlin, 2019). The same can be said about pre-service teachers. According to Aslan and Chang (2016), although pre-service teachers do use technology more than in-service teachers, their skills tend to be limited to technologies they are familiar with: using search engines to look for information and employing a data-projector to project PowerPoint presentations.

This situation makes it clear that we need to expose pre-service students to new technologies, technologies that they can use to present content in ways that enhance learning. Especially in the context of the ongoing pandemic, it is important to help students imagine how they might engage technology to create their own resources for classroom use, rather than just exploiting technology to repeat content to learners. As stated above, the module that is the focus of this study aimed at developing and facilitating students' digital competencies to enable them to create their own resources for use in the classroom, and in doing so develop their knowledge, skills and attitudes toward new approaches and resources for the language classroom.

\section{Creating their own resources}

If there is one thing in education that the exigencies of COVID-19 have taught us, it is the need for teachers to be able to create their own resources and make use of technology. Although numbers of learners do not have access to devices like iPads or the internet and thus could not avail themselves of resources while the schools were closed, now that they are back at school teachers need to think critically and creatively about how to help them to catch up. Teachers therefore need the digital competencies to make smart decisions.

A critical problem in language education and film in South Africa is gaining access to resources in the language that is being taught, especially the African languages and to some extent Afrikaans. Most films are only available in English, so teachers will just use the English film or no film at all. Giving students guidance on how they might use technology to create films in their language of choice is a way to decolonise the curriculum while imparting vital skills. 
Marais, E. A journey through digital storytelling during COVID-19: Students' preparedness to use technology for learning in the language classroom

The challenges posed by the pandemic gave the author the opportunity to combine the development of digital competencies and home language resources as an activity for her preservice student teachers.

\section{Methodology}

The research methodology sets out the procedures that was followed by the researcher answers the research question and is defined as the methods, facts and epistemological approach used (Creswell \& Cresswell, 2017). In this section the task that was assigned to the students will also be discussed.

\section{The task assigned to students}

The assessment that the students had to complete was as follows:

Use an animation film like Tom and Jerry or any other animated film that you see as appropriate to teach Afrikaans. As part of the assignment, you have to do the following:

1. Choose a short animated film, such as Tom and Jerry, that you deem appropriate for a particular grade.

2. Write an appropriate text (in the drama format) for the short animated film. Look at Study Unit 1 for the characteristics of a drama.

3. Recreate the film by recording your drama as a voice-over with the animated film.

4. Use this newly created film to prepare a listening and speaking lesson to be used in a school classroom. Remember to integrate language components into your lesson.

What you have to submit:

1. Your drama text.

2. Your reworked film.

3. 300 to 500 words on how you would use this film to teach a lesson.

4. 300 to 500 words on why you have chosen this specific film for the Intermediate Phase.

The lecturer supported the students by helping them through technical difficulties they might encounter while recording their videos. Instructions were included on how to record their videos by using either their phones or screen recorders, and how to re-size them.

In this assignment, students had to demonstrate the characteristics of a drama by writing their own drama (thereby enabling assessment of their knowledge about drama) (lower level of Bloom's taxonomy). They then had to create a short film, as well as analyse and evaluate it (top levels of Bloom's taxonomy). For the final part of the assignment, the students had to submit not only a rationale for choosing the film and but also an explanation for why the film was appropriate for that particular grade, and how it could be used in the classroom. This displayed their ability to understand the context of their learners and apply the knowledge they had gained during the course to make decisions on how to use drama and film in the classroom. 
Marais, E. A journey through digital storytelling during COVID-19: Students' preparedness to use technology for learning in the language classroom

This assignment was not only aligned constructively with the outcomes of the module but also modelled to students that they could create their own resources and think critically about them.

In the end, the activity addressed five fundamental elements, as illustrated below in Figure 1: using the content the students had to learn from the curriculum to create their own resources for the classroom, and in doing so develop their digital competencies. Having the opportunity to share their films further developed their engagement not only with the content of the module but how resources could be created, as students could see how others did it and could learn from each other in a community of practice.

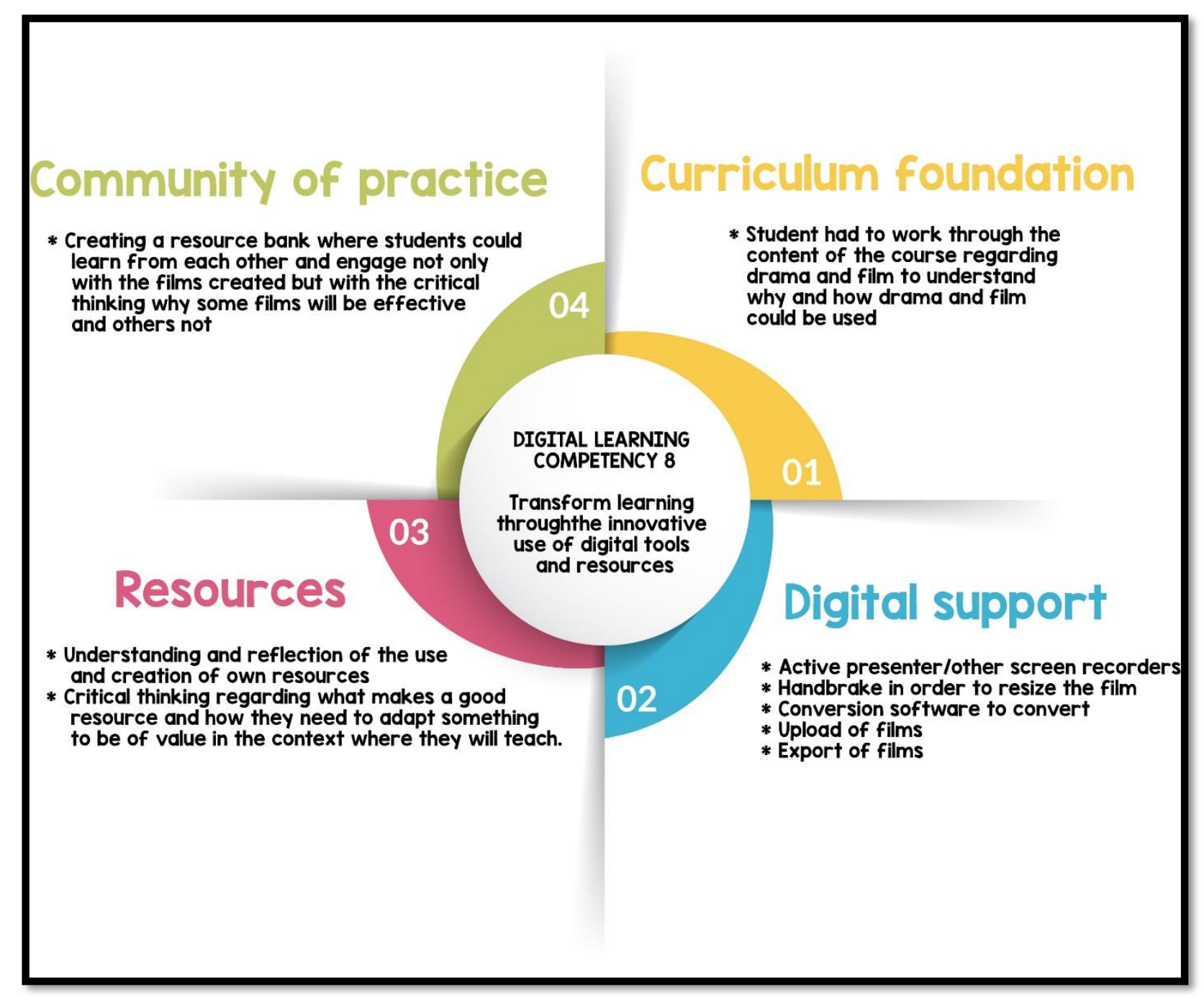

Figure 1: Development of the activity (Produces by the Author)

While the lecturer had a clear concept and goal in mind for the task, it is important to evaluate what students learned and got out of the experience. To evaluate the students' perceptions of the task and the digital competencies learned, a questionnaire was distributed to them. students. The following section will discuss the methodology and the results of the questionnaire. 
Marais, E. A journey through digital storytelling during COVID-19: Students' preparedness to use technology for learning in the language classroom

\section{Research Question}

In this study the following research question was explored:

- How can digital storytelling be used to develop students' digital competencies and own resources while assessing their content knowledge regarding drama in film in language teaching?

\section{Research design}

In order to answer this question, a qualitative research approach within the interpretive paradigm was adopted. Qualitative research is conducted to understand people's experiences and provides an opportunity to understand what is important for people(Creswell \& Cresswell, 2017; Silverman, 2020) or in the case of this study students experience of the task that was assigned to them to develop resources and their digital skills in this particular course. The interpretativist paradigm is used as it as it gives the researcher the freedom to explore the meaning that an individual or an community may extrapolate from an experience (Creswell \& Cresswell, 2017; Rehman \& Alharthi, 2016). According to Rehman and Alharthi (2016) "researchers are inextricably part of the social reality of being researched, i.e. they are not 'detached' from the subject they are studying" (p.83) as the lecturer (researcher) was in the case of this study.

\section{Participants}

The research was treated as a case study through the purposive sampling of students completing the course detailed below. A case study is an research approach that is used to gather in-depth, multi-faceted understanding of participants' experience of a particular phenomenon or situation (Creswell \& Cresswell, 2017). Purposive sampling is widely used in such qualitative research (Palinkas et al., 2015)to unpack and explore information-rich cases that relates to the phenomenon that is being studied. The population for this study included a cohort of student teachers completing a degree in education focused on the Intermediate phase of the South African school curriculum. All students in this population was registered for AFRI 311, (Afrikaans Home Language, Afrikaans Film and Drama), a compulsory module in this programme. 84 Students from a class of 116 participated in this study after being invited to complete a questionnaire about their experiences of completing the assessment task for this module.

\section{Research instrument and data collection}

The Cirrus testing platform was used to conduct an open-ended questionnaire. Cirrus is a cloudbased, e-Assessment tool hosted by Amazon Web Services that is incorporated within this institution's Learning management system (Cirrus, 2021). Using Cirrus provided a platform that participants were already familiar with and therefore did not add to their coursework or workload. The Cirrus testing platform was adapted to only use open-ended questions that would not be marked but where students could give their honest opinions.

\section{Data analysis}

The responses to the open-ended questions were downloaded in excel format and coded using ATLAS.ti. ATLAS.ti is an computer program used to arrange and manage qualitative material in 
Marais, E. A journey through digital storytelling during COVID-19: Students' preparedness to use technology for learning in the language classroom

creative and systematic ways in for data analysis purposes (ATLAS.ti, 2021). The qualitative data that was gathered from the questionnaire was subsequently evaluated and interpreted to answer the research question set out above.

Three following themes were identified from the data:

- Pre-service teachers' preparedness to utilise technology to create a film as a digital resource;

- Pre-service teachers' perceptions of the ease of use of new technology as a vehicle to present content;

- Pre-service teachers' perceptions of creating their own resources; and

- Students learning from each other.

Ethical clearance was obtained from the North-West Ethical committee within the Faculty of education within the WILWORKS project. In another effort towards ethical behaviour, participants were offered the opportunity to answer the open-ended questions in their home language, Afrikaans, in order to create a safe space to express their views. This also contributed to validity and reliability of the data.

As responses to the questionnaire was in Afrikaans, the direct quotations were translated to English for the purpose of this article. Member checking and triangulation were performed as the translations were sent to the students for their approval of the content and understanding.

\section{Findings and Discussion}

\section{Pre-service teachers' preparedness to utilize technology to create a film as a digital resource}

Initially, students were negative about the use of new technology as most of the students, 73 of the 84 who responded, indicated that they had never done anything like this before. Only 9 students indicated that they did not learn any new digital skills. The majority of students therefore had no pre-existing knowledge about using a film that was already created and reworking it into something new. One student commented that he/she did not understand the need for resources in the home language, as an English film would do just as well.

S41:1: I would not create such a film again, I do not see the need to create films in Afrikaans for students, they can watch the English as it was created in English. I would just rather use it as is.

Most students' knowledge about technology was limited to word processing and watching videos, not creating their own. Some students indicated that while they created TikTok videos, this was something totally different, as TikTok videos are much shorter and do not fall into the criteria as set out in the assignment.

Their initially negative attitudes spilled over into an unwillingness to learn new technology. They did not want to try something new, and several students asked if they could present their content on PowerPoint. It was evident from the students' growing preparedness to try the new technology that they were moving through the stages of concern identified by George et al. (2006). This process was described by George et al. (2006), to explain how likely a person might be to adapt to new technology based on their concerns regarding that technology. According 
Marais, E. A journey through digital storytelling during COVID-19: Students' preparedness to use technology for learning in the language classroom

to George et al. (2006), the stages of concern that might influence the adoption of new technologies can be set out as follows:

\begin{tabular}{|l|l|l|}
\hline 6 & Refocusing & $\begin{array}{l}\text { The individual focuses on exploring ways to reap more universal } \\
\text { benefits from the innovation, including the possibility of making } \\
\text { major changes to it or replacing it with a more powerful alternative. }\end{array}$ \\
\hline 5 & Collaboration & $\begin{array}{l}\text { The individual focuses on coordinating and cooperating with others } \\
\text { regarding use of the innovation. }\end{array}$ \\
\hline 4 & Consequence & $\begin{array}{l}\text { The individual focuses on the innovation's impact on students in his } \\
\text { or her immediate sphere of influence. Considerations include the } \\
\text { relevance of the innovation for students; the evaluation of student } \\
\text { outcomes, including performance and competencies; and the } \\
\text { changes needed to improve student outcomes. }\end{array}$ \\
\hline 3 & Management & $\begin{array}{l}\text { The individual focuses on the processes and tasks of using the } \\
\text { innovation and the best use of information and resources. Issues } \\
\text { related to efficiency, organizing, managing, and scheduling } \\
\text { dominate. }\end{array}$ \\
\hline 2 & Personal & $\begin{array}{l}\text { The individual is uncertain about the demands of the innovation, his } \\
\text { or her adequacy to meet those demands, and/or his or her role with } \\
\text { the innovation. The individual is analyzing his or her relationship to } \\
\text { the reward structure of the organization, determining his or her part } \\
\text { in decision making, and considering potential conflicts with existing } \\
\text { structures or personal commitment. Concerns also might involve the } \\
\text { financial or status implications of the program for the individual and } \\
\text { his or her colleagues. }\end{array}$ \\
\hline \multirow{2}{*}{$\begin{array}{l}\text { Informational } \\
\text { Unconcerned }\end{array}$} & $\begin{array}{l}\text { The individual indicates a general awareness of the innovation } \\
\text { and interest in learning more details about it. The individual does } \\
\text { not seem to be worried about himself or herself in relation to the } \\
\text { innovation. Any interest is in impersonal, substantive aspects of } \\
\text { the innovation, such as its general characteristics, effects, and } \\
\text { requirements for use. }\end{array}$ \\
\hline $\begin{array}{l}\text { The individual indicates little concern about or involvement with } \\
\text { the innovation. }\end{array}$
\end{tabular}

Figure 2: Stages of concern regarding the adoption of new technology (George et al., 2006)

According to George et al. (2006), concerns about adopting new technology will vary according to the user's knowledge and experience of that particular technology, and these concerns will influence the intensity of their adoption of the new technology.

When the assignment was first presented to the students, they were 'unconcerned' about the new technology and did not want to use it. Numbers of students indicated that their first response to the assignment was one of panic as they felt that they did not have the digital skills to complete it, and would have preferred the familiarity of a medium like PowerPoint. As time elapsed and students realised that they would have to complete the assignment, their concerns about the new technology moved to a personal concern regarding 'what do I need to do?' (George et al., 2006). In this stage of concern, the students were uncertain about the demands of the new technology and their ability to meet these demands. 
Marais, E. A journey through digital storytelling during COVID-19: Students' preparedness to use technology for learning in the language classroom

Creating a space of support was crucial in this regard, a space where not only support videos were supplied but where questions were answered immediately. Students felt comfortable enough to try new things with new technology. Thereafter they learned by doing.

\section{Pre-service teachers' perceptions of the ease of use of new technology as a vehicle to present content}

Ample support was given to students to make sure that they did not struggle with the creation and uploading of a video. The lecturer explained everything via short instructional videos that were sent to students on the Learning Management System and via a WhatsApp group. The students could ask questions on the WhatsApp group and support could be given to them as they needed it. It was important to ensure that students' struggles with technology did not influence them negatively. If students struggled with recording, presenting and reworking their video, the Supplemental Instruction leader ${ }^{1}$ was there to supported them.

It was also important to make sure that students knew exactly what they would be assessed on. The assessment focused on content knowledge, as this was the main focus for the incorporation of film with a written assignment, and not necessarily how it looked. Secondly, students were assessed on the presentation of their film in relation to the school grade for which they had created it.

After students had overcome their initial 'fear' of the new application, they were asked in the survey what they thought of various aspects of it. As many as 79 of them indicated that they would be using the tools to which they had been introduced again to create their own resources for their classrooms. Forty-eight of the participants indicated that although it was difficult at the beginning, with support they were able to learn new digital skills that they could transfer to other fields within their careers. The 5 students who indicated that they would not be making or using such films in their classrooms gave very different answers for this. One student commented that she would much rather use the English version of the film, even in an Afrikaans Home Language class (see quote S41:1). This is quite unfortunate as we have a big problem in South Africa with access to resources in Afrikaans and the other nine official languages. It seems that we have not made it sufficiently clear to our students that when you give a learner resources in the language that you are teaching they will learn the language better. It was therefore important to have a follow-up session with the class to reiterate why resources in the home language being taught are extremely important.

Another comment that spoke to why students would not use film again in this way had to do with their interface with the new technology. The student commented that it takes too long and it is not as perfect as Hollywood animation would be.

S56:5: I struggled to create a perfect Hollywood Film and it took really long, I don't think that I will do it again although I think children will enjoy it.

\footnotetext{
${ }^{1}$ An supplemental Instruction leader is an senior student that support students within a subject if and when they struggle. They do not lecture, but support students in question that they have and as a group the students solve the problems and learn from each other.
} 
Marais, E. A journey through digital storytelling during COVID-19: Students' preparedness to use technology for learning in the language classroom

This is unfortunate. As teachers, they will not have the financial capacity to create Hollywood films, and if this is their outlook they will never give their students access to films in a language other than English.

\section{Pre-service teachers' perceptions of creating their own resources}

The students were asked if they would create such films again and use the films that they had created in their classrooms. To this question the answer was an overwhelming 'yes', with the exception of two students. The students who responded that they would use these resources in their classroom commented that the films helped them to explore the availability of films in the home language in question, and now saw the need for them.

They furthermore commented that having the creative space to write the story and then create the film had them thinking more deeply about what is appropriate for the Intermediate phase and how they would use this kind of material in their classroom. One student commented that she wanted to teach a lesson about intensive form. Using an already created film would not necessarily use intensive form that the teacher could use as part of their lesson, but seeing that she had created the dialogue she had the freedom to make sure that intensive form phrases were included.

S12:3: I struggled but enjoyed creating the dialogue that could support my lesson. I wanted to do a lesson on intensive form, but no film includes this, especially in Afrikaans. Writing the dialogue, I could include it to correlate with my lesson.

The two students who commented that they would not use or create such films again had two different arguments regarding the matter. One student indicated that it takes too much time to create your own resources, while the other commented that s/he does not see the need to give learners the resources in the language that s/he is teaching. She stated that they can watch the English film and just answer questions in the language being taught.

S76:3: I would not create my own film, you would save time to just use resources that the school have, or the department gives you, even if they are not available in Afrikaans. It takes too much time to write the words and create the film.

Both of these are problematic responses, as the one indicates a fundamental problem - that some students and teachers only want to use the resources they have, no matter the circumstances - and the other suggests that the student does not understand the fundamental principles of language instruction, i.e., giving students a chance to experience the language.

\section{Students learning from each other}

Although this was not originally planned, the films and drama texts that the students created were shared among them after they had submitted their work. Most students indicated that it broadened their understanding and that they learned from each other. The students had a resource bank they could use for teaching practice and when they taught in the future. Putting together this resource bank pooled resources not only for the students but also for the larger community if the students were to give their consent. 
Marais, E. A journey through digital storytelling during COVID-19: Students' preparedness to use technology for learning in the language classroom

The fact that students were able to watch other students' films allowed them not only to see different and creative ways that other students presented their drama and used Afrikaans Home Language in animated films, but also engendered an awareness of variance in Afrikaans, as coming from different contexts in the diverse society of South Africa, the students speak different variants of the language.

Students further indicated that the assignment held their attention and incorporated creativity: it motivated them to think differently about language teaching and the resources they could use and even create. This was evident when students had to create content and resources later on in the course, when several students made use of film instead of traditional assignment types. Some students attempted even more unusual and original exercises. When I asked these students why they tried the format that they did, they indicated that the creativity encouraged in the course spurred them to think outside of the box and take things a step further. This is evident from some of these quotes:

S8:5: It was nice for me to be a bit creative I enjoyed the opportunity to be creative and to create my own resources it was a positive experience that aided me to think outside of the box and prompted me to think about ways to create resources to support my learners.

S26:3: It was really creative and different. This challenged me to think differently not only about teaching language, but about resources.

Students indicated that the 'different' approach that was used within this module led them to examine language education and look differently at the teaching of the various language components. They said that their experience in school and hitherto during the teaching practice opportunities had induced them to see language teaching as boring and textbook bound. They have felt that children did not enjoy it and that they had not known how to make it interesting for them.

When asked whether this new approach had changed their views on language teaching, the students indicated that it had indeed made language teaching more interesting [S6:2: "It was really interesting way to present a lesson in the language classroom"]. They claimed that they had been allowed more creativity, and that this had changed their own approach to language teaching. They indicated that they would like to make language teaching more creative and engaging for learners, by using modern teaching approaches and technology.

\section{Conclusion}

Finding a way to critically engage students during COVID-19 pandemic with film and how they would use it within an Intermediate classroom created a challenge for me as a lecturer. I was always very reliant on the lively discussions that showing films to students engendered, especially their ideas about one would use a particular film in the classroom and the value of doing so. The advent of the pandemic required me to think differently and go beyond the creation of a zoom classroom where some students could end up not attending or muting their microphones or even doing something else while the discussion proceeded.

Challenging the students to create their own films developed their digital learning competency by transforming learning through the innovative use of digital tools and resources. This in turn 
Marais, E. A journey through digital storytelling during COVID-19: Students' preparedness to use technology for learning in the language classroom

challenged and developed the students' spirit of innovation, their exploration of the value of technology and their thinking about new ways of learning and teaching. The activity described in this article challenged the students to engage with the content and to understand it thoroughly: not only by creating a drama but by thinking critically about why, how and what the true value is of what can be created in the language classroom. Each student had to engage on his or her own but with the opportunity to ask questions and learn. From the students' feedback, it is clear that the assignment did push them out of their comfort zone, but they rose to the challenge and in the end acquired not only content and pedagogical knowledge but also digital competencies, rendering them more prepared for the changing world in which they would be teaching.

\section{References}

Ahn, C. (2020, May). Engaging Students in Film Analysis in ELA Classrooms. https://facingcanada.facinghistory.org/engaging-students-in-film-analysis

Aslan, A., \& Chang, Z. (2016). Influencing Factors and Integration of ICT into Teaching Practices of Pre-service and Starting Teachers. International Journal of Research in Education and Science (IJRES), 2(2), 13.

ATLAS.ti. (2021). What is ATLAS.ti. https://atlasti.com/product/what-is-atlas-ti/

Cirrus. (2021). Cirrus: Create better assissments. https://cirrusassessment.com/

Creswell, J. W., \& Cresswell, J. D. (2017). Research Design: Qualitative, Quantitative, and Mixed Methods Approaches (5th ed.). SAGE Publications.

De Villiers, J. (2019). 17 key announcements in the State of the Nation address - including the new eVisa and free tablets. Business Insider. https://www.businessinsider.co.za/keyannouncements-in-ramaphosas-state-of-the-nation-address-2019-2

George, A. A., Hall, G. E., \& Stiegelbauer, S. M. (2006). Measuring Implementation in Schools: The stages of concern questionnaire.

Hammond, M., Crosson, S., Fragkouli, E., Ingram, J., Johnston-Wilder, P., Johnston-Wilder, S., Kingston, Y., Pope, M., \& Wray, D. (2009). Why do some student teachers make very good use of ICT? An exploratory case study. Technology, Pedagogy and Education, 18(1), 59-73. https://doi.org/10.1080/14759390802704097

Jackman, J. A., Gentile, A., Cho, N., \& Park, Y. (2021). Adressing the digital skills gap for future education. Nature Human behaviour, 5(May 2021), 542-545.

Koehler, M., Mishra, P., \& Cain, W. (2013). What Is Technological Pedagogical Content Knowledge (TPACK)? Journal of Education, 193(3), 7.

König, J., Jäger-Biela, D. J., \& Glutsch, N. (2020). Adapting to online teaching during COVID-19 school closure: teacher education and teacher competence effects among early career teachers in Germany. European Journal of Teacher Education, 43(4), 608-622.

Marais, L. (2020). AFRI311: Drama en Film vir die Onderwys. Potchefstroom: North-West University

Martines, I. G., Pérez-Ferra, M., Jiménez, J. L. U., \& Quigano-López, R. (2019). Promoting Professional Development for Teachers Through a Scale of Competence Assessment. Research in Social Sciences and Technology, 2(19), 147-162. 
Marais, E. A journey through digital storytelling during COVID-19: Students' preparedness to use technology for learning in the language classroom

Ohlin, C. (2019). Information and Communication Technology in a Global World: Teachers' Perceptions of Continuing Professional Development. Research in Social Sciences and Technology, 4(2), 41-57.

Organization, I. L., \& Bank, W. (2021). Skills development in the time of COVID-19: Taking stock of the initial responses in technical and vocational education and training. I. L. Office.

Palinkas, L. A., Horwitz, S. M., Green, C. A., Wisdom, J. P., Duan, N., \& Hoagwood, K. (2015). Purposeful sampling for qualitative data collection and analysis in mixed method implementation research. Administration and Policy in Mental Health and Mental Health Services Research, 42(5), 533-544.

Perifanou, M. (2021). Teachers' Digital Skills Readiness During COVID-19 Pandemic. International Journal of Emerging Technologies in Learning, 16(8), 238-251.

Rehman, A. A., \& Alharthi, K. (2016). An Introduction to Research Paradigms. International Journal of Educational Investigations, 3(8), 51-59.

Robin, B. R. (2016). The Power of Digital Storytellingto Support Teaching and Learning. Digital Education Review. https://files.eric.ed.gov/fulltext/EJ1125504.pdf

Robinson, K., \& Aronica, L. (2015). Creative schools: Revolutionizing education from the ground up. Pengiun UK.

SA. (2004). White Paper on e-Education: Transforming Learning and Teaching through Information and Communication Technologies (ICTS). Cape Town

SA. (2011). Kurrikulum- en assesseringsbeeidsverklaring: Intermediêre fase Graad 4-6, Afrikaans Huistaal. Cape Town: Government Printing Works

SA. (2019). Professional development framework for digital learning. Pretoria: Department of Basid Education

Silverman, D. (2020). Introducing Qualitative Research. In D. Silverman (Ed.), Qualitative Reserach (pp. 3-16). SAGE Publisers.

Stephens, C., Ascencio, R., Burgos, A. L., Diaz, T., Montenergo, J., \& Valenzuela, C. (2012). Film Circles: Scaffolding Speaking for EFL Students.

Tamika, K. W., Mclntosh, R. W., \& Russel III, W. B. (2021). Equity in Distance Education During COVID-19. Research in Social Sciences and Technology, 6(1), 1-24.

Tondeur, J. (2018). Enhancing future teachers' competencies for technology integration in education: Turning theory into practice. International journal of media, technology and lifelong learning, 14(2), 9.

Tondeur, J., Pareja Roblin, N., van Braak, J., Voogt, J., \& Prestridge, S. (2016). Preparing beginning teachers for technology integration in education: ready for take-off? Technology, Pedagogy and Education, 26(2), 157-177. https://doi.org/10.1080/1475939x.2016.1193556

Tondeur, J., Scherer, R., Baran, E., Siddiq, F., Valtonen, T., \& Sointu, E. (2019). Teacher educators as gatekeepers: Preparing the next generation of teachers for technology integration in education. British Journal of Educational Technology. https://doi.org/10.1111/bjet.12748

Walton, S. (1992). Sam Walton: Made in America. Bantam Books. 